\title{
THE FACTORS AFFECTING ENTREPRENEURSHIP INTENTION
}

\author{
Irine HERDJIONO ${ }^{1}$, Yeni Hastin PUSPA ${ }^{2}$, Gerzon MAULANY ${ }^{3}$ \\ Musamus University ${ }^{1,2,3}$ \\ 'Benedictus Elnath ALDY4, \\ Atmajaya University ${ }^{4}$
}

\begin{abstract}
This research examined the effects of family environment, self concept, motivation and risk taking propensity on entrepreneurship intention in Merauke, the border area of Indonesia. Conducted by collecting data from 382 college student through questionnaire. This study applied linear regression analysis. The results showed family environment, self concept, motivation and risk taking propensity significantly affected entrepreneurship intention. The study implies that individual factor such as self-concept, motivation, and risk taking propensity together with social factor, family environment affect entrepreneurial intention.
\end{abstract}

\section{KEYWORD}

entrepreneur, family, intention, motivation, risk, self-concept,

JEL: A10, A22

\section{INTRODUCTION}

Nowadays, many college graduates prefer to work as employee in a company or becoming government employee. Only few of them think to create self-employment or become entrepreneur due to lack of confidence in their skill and capital.

According to the employment in 2013, the amount of unemployment reached 8,286 people and 6,613 people in 2014. Meanwhile, the amount of labor force increased into 114,331 people in 2014 and 106,596 in 2013. In percentage, Open Unemployment Rate (OUR) in 2013 reached 7.77\%, and decreased $5.78 \%$ in 2014 . The employment in 2013 reached 98,310 people, it has increased into 107,718 people. While, the unemployment rate with high education level in Merauke in 2014 amounted 306 people with labor force amounted 9,628 people and employment level amounted 9,322 people. In percentage, the Open Unemployment Rate (OUR) reached 3.18\%.

The amount of government employee vertically or autonomously in 2013 amounted 3,937 people and 9,085 people in 2014. Meanwhile, the amount of formal, informal, and medium enterprise in 2014 amounted 851 units and 804 units in 2013. This condition shows both the total amount of formal, informal, medium enterprise and government employee vertically and autonomously.

1,2,3 Correspondence address: Musamus University, Kamizaun Mopah Lama Merauke, Papua, Indonesia. Email: irene.herdjiono@gmail.com

4 Correspondence address: Atmajaya University, Jend. Sudirman No.51 Jakarta, Indonesia. Email: aldi.elnath@gmail.com 
Unemployment occurs due to many factors, one of them is because of the limitation of job opportunities. Many college graduates become unemployment because practically they want to become government employee or in other words be a job seeker instead of a job creator.

According to the unemployment condition in Merauke and one of the effort to overcome is by encouraging individual to be a job creator, so the purpose of this research is to examined the effects of family environment, self concept, motivation and risk taking propensity on entrepreneurship intention in Merauke, the border area of Indonesia. The study adds to literature of entrepreneurship intention in emerging countries especieally in border are of a country. The border area usually has problem living in education and economy that's needed to explore factors that solve the problem through entrepreneurship.

\section{LITERATURE REVIEW}

The willingness in becoming entrepreneurship are determined by some factors such as family, motivation, risk taking propensity or the courage to take a risk, and self-concept as individual factor (Tyszka et. al., 2011, Belas and Klujnikov, 2016). Belas and Klujnikov (2016) conclude that entrepreneurs consider expertise, responsibility and perseverance to be the most important personal characteristics, skills, propensity to risk and decisiveness.

\section{FAMILY ENVIRONMENT}

Shapero (1982) conclude that father or mother have powerful role in establishing the desirability of the entrepreneurial behavior. Entrepreneurial intentions increases through socialization process. Family environment and all conditions within its family including how parents educate, family members relation, house condition, family's financial condition, parents understanding, and cultural background will support, guide, and encourage children to their future life, Aldrich \& Cliff (2003) present conceptual framework based on a family embeddedness perspective on new venture creation. The framework emphasizes how the characteristics of entrepreneurs' family systems (i.e., transitions, resources, and norms, attitudes, and values) can influence the processes involved in venture creation (i.e., opportunity recognition, the launch decision, resource mobilization, and the implementation of founding strategies, processes, and structures).

Research done by Lindquist et al., (2015), Fatoki (2015) state that family environment gives positive influence on the willingness in entrepreneurship. Parental support will influence the willingness in doing entrepreneurship.

\section{SELF-CONCEPT}

Self concept is the concept the individual has of himself as a physical, social, and spiritual or moral being (Gecas, 1982).Self-concept has three components-perceptual, conceptual attitudinal (Kumari and Chamundeswari, 2013). Perceptual Component mostly called as physical concept which is an image on someone about physical appearance and impression about others. Conceptual Component is someone's concept about special characteristic, strength and weakness, future background, and so on. It is called as psychology self-concept. Attitude Concept is more likely a feeling felt by someone about himself, attitude about his current or future condition, attitude about self-pride, proud, ashamed feeling, etc. After he grown up, this attitude concept involves believes, aspiration value, commitment, and so on which forms his philosophy as well. 
Research done by Simanjutak et al., (2016) states that self-concept influence potential entrepreneurship. The better the self-concept, the more motivation in doing entrepreneurship and vice versa. Positive self-concept leads to optimism about the future and courageous if having a failure. Entrepreneurs revealed more confidence than employees (Tyszka et al., 2011).

\section{ENTREPRENEURSHIP MOTIVATION}

Motivation in entrepreneurship including directed motivation to achieve the purpose of entrepreneurship, like the purpose that involves introduction and exploitation about business opportunity (Baum, 2007). Motivation is an encouragement to work hard to obtain many things such as earning profit, freedom, personal dream, and independent.

Four motivations to do entrepreneurship; profit, personal freedom, personal dream, and independen. Profit can motivate someone to be an entrepreneur because it can be used to determine how much profit he wants, the benefit received, and how much the cost will be paid to other parties or employee. The freedom to manage time, set the rule/intervention, and freedom from cultural rule in organization or company. Personal dream is something that individual desired about, including the freedom to achieve the expected life standard, tired routine work because he has to follow vision, mission, and others dream. The reward to determine its vision, mission, and dream. Independent can motivate a person in doing entrepreneurship because the absence of dependent on others. Independency can cause a sense of pride because it creates self-sufficient in all respects such as capital, management, supervision, as well as become a manager against himself.

Motivation influences positively on the willingness in doing entrepreneurship because it can trigger enthusiasm or interest in doing certain activity so it will trigger innovative thinking in making profit business. Entrepreneurs'motivation are the need for independence and the need for achievement (Tyszka et al.2011)

\section{RISK TAKING PROPENSITY (COURAGE TO TAKE RISK)}

The willingness and ability to take risk is one of the main point in entrepreneurship. Entrepreneur who dislikes risk will have difficulty in initiate. Entrepreneur is not afraid in taking chances with respect to risk by evaluating the size of risk. In every opportunity, an entrepreneur will always avoid high risk. They realize that high achievement occurs when they are willing to take risk as the consequence in achieving purpose. Risk taking is related with self-confidence. It means that the greater the person's belief in his ability, the greater the person's belief in its competency to influence result and decision, and the greater the person's readiness to try what the others perceive as risk.

In decision making, a business people or an entrepreneur should consider the possibility of risk. An entrepreneur is called as risk averse, loss averse, and risk profile.

1. Risk Aversion and Loss Aversion

Risk aversion is a concept that described about how large someone's willingness to sacrifice its resources in order to get uncertain results. Risk aversion can be illustrated as individual decision to choose to get $\$ 50$ instead of getting $\$ 100$ with probability $50 \%$. In other words, risk aversion is a tendency to avoid risk or taking opportunity without risk.

Loss aversion is an individual decision to avoid loss on the effort to earn profit or in other words the unwillingness to bear the risk.

\section{Entrepreneur and Risk Profile}


Risk profile is a different perception between investor and employee because different experience had by them. Investors' experience will increase his ability to measure risk. Investor often experience a situation that required himself to make a decision. Different condition happens for employee who doesn't allow himself to make decision because it depends on the boss or shareholders.

Risk taking propensity or the courage to take risk is a courage to take chances with respect to risk by always measuring the size of the risk, so that individual can make decision not to take on too high or low risk. According Bezzina (2010), risk taking propensity is a tendency to take risk after analyzing each situation carefully and they have developed a strategy to minimize the impact of its risk. Bezzina (2010) mentions several indicators of risk taking propensity such as:

a. The intention to take risk

1. Investing higher capital to take business opportunity

2. Taking risk to earn benefit

b. Develop a strategy to minimize the impact of its risk

1. High risk for high return

2. Risk free business plan

Risk taking propensity or the degree to which an entity is willing to take chances with respect to risk can create opportunity and give people opportunity as well. Risk taking propensity or the willingness to take chances with respect to risk is one of the factor in encouraging people to be an entrepreneur rather than people who dislike risk or risk aversion. Furthermore, better self-concept and supportive environment can drive motivation to become a successful entrepreneur.

Research done by Bezzina (2010) finds that risk taking propensity or the willingness to take chances with respect to risk gives positive and significant impact toward intention to do entrepreneurship, an entrepreneur will take risk after analyzing the situation carefully and develop a strategy to minimize the effect of its risk. An entrepreneur is risk aversion and loss aversion. Risk aversion means the intention to avoid risk while loss aversion means the unwillingness to bear the risk.

People who have the interest in entrepreneurship are necessary to have risk taking propensity so that the capital is not the most important thing to start entrepreneurship. An entrepreneur should have an intention to have a good risk profile compare with an employee, so that an entrepreneur is aware that future business growth is the result of current business opportunity to achieve business objectives. Therefore, to start an entrepreneurship it needs risk taking propensity. If an entrepreneur is unwilling to take risk (risk aversion), then he will never be able to realize the talent and spirit of entrepreneurship. Belas et al. (2015) conclude that the most important business risk is market risk.

\section{RESEARCH METHOD}

\section{Hypothesize}

\section{a. The affect of Family Environment on the Entrepreneurship Intention}

Family environment that may affect children's behavior in achieving the successfulness in entrepreneurship is by working hard and never give up are the best way to train children's interest in choosing job. Parent's condition as a condition in the family environment can be a figure in selecting children's occupation. Children's interest will not be strong enough if it is only nurtured and molded through the experience without the encouragement and guidance from parents. Although there is a strong interest in children and they are able to be an entrepreneur, without 
strong parental support on their area, then there is a chance that children will feel less confident or even no longer want to pursue their desires.

Family environment has positive influence on the willingness of doing entrepreneurship (Lindquist et al., 2015, Fatoki, 2015). Parental support like supporting entrepreneurship activity will influence the willingness in doing entrepreneurship. From those explanations, so the hypothesis can be formulated as follows:

\section{H1: Family environment effect entrepreneuship intention}

\section{b. The effect of Self-Concept on the Entrepreneurship Intention}

Self concept influenced the entrepreneurship potential (Simanjutank et al., 2016, Utsch and Rauch, 2000; Mueller and Thomas, 2001; Nga and Shanmuganathan, 2010). There were two self-concept which is positive self-concept in which a person is more likely has high self-confidence, he views a failure as a delayed success. Therefore, it makes a person believes in the successfulness of entrepreneurship because he is able to see every business opportunity. Having negative self-concept like having no self-confidence making it difficult to put his interest in entrepreneurship and always pessimistic about the future which indirectly prepared himself for failing. Through this positive concept, it is useful to recognize the environment, see the opportunity, and use resources in order to take advantage of these opportunities and believes that the products and services offered have advantages over the others.

Based on that explanations, so hypothesis can be developed into:

\section{H2: Self-concept effect the entrepreneurship intention}

\section{c. The Effect of Motivation on the Entrepreneurship Intention}

Motivation is the encouragement to work hard in order to obtain many things such as the desire to become successful entrepreneur, so that it can induces passion in giving positive response on the opportunity in obtaining the maximum benefit for himself so he doesn't depend on others. That advantage can be achieved by always serving customer nicely and create more efficient working system to create creative and innovative products. The higher the motivation in entrepreneurship, the more business successfulness will be supported. Because higher motivation will make a person be able to overcome any difficulties and he also be able to create the solution.

\section{H3: Motivation effect the entrepreneurship intention}

\section{d. The Influence of Risk Taking Propensity on the Interest in Entrepreneurship}

Liles (1974) argued that entrepreneurs often must accept uncertainty with respect to financial wellbeing, psychic well-being, career security, and family relations. Entrepreneurs tend to take risk after analyzing the situation carefully and they have developed a strategy to minimize the impact of it's risk (Bezzina, 2010). In general, a group with entrepreneurial activity has more prominent characteristics of risk taking propensity than the other groups. Result from Bezzina (2010), Hmieleski and Corbett (2006), Gürol and Atsan (2006) shows a positive and significant correlation between risk taking and the intention of entrepreneurship.

\section{H4: Risk taking propensity influences the interest in entrepreneurship}

2. Variables and Measurement 
Variables in this study consisted of four independent variables and one dependent variable. Variable definition and measurement presented in Table 1.

Table 1. Operational Definitions Variables

\begin{tabular}{|l|l|}
\hline \multicolumn{1}{|c|}{ Variables } & \multicolumn{1}{c|}{ Definition } \\
\hline $\begin{array}{l}\text { A. Independent } \\
\text { a. Family Environment }\end{array}$ & $\begin{array}{l}\text { Insititution that the firs and major influence on life, growth } \\
\text { and development of children through interact with members } \\
\text { of family, attention given, situation of the house and } \\
\text { family's economic circumstances } \\
\text { The concept the individual has of himself as a physical, } \\
\text { social, and spiritual or moral being } \\
\text { encouragement to work hard to obtain many things such as } \\
\text { earning profit, freedom, personal dream, and independent } \\
\text { a courage to take chances with respect to risk by always } \\
\text { measuring the size of the risk }\end{array}$ \\
c. Motivation & $\begin{array}{l}\text { d. Risk Taking Propensity } \\
\text { to start a new enterprise or create new core value in existing } \\
\text { organization }\end{array}$ \\
\hline $\begin{array}{l}\text { Entrepreneurship Intention } \\
\text { (Khuong, Huu An, 2016) }\end{array}$ & \\
\hline
\end{tabular}

\section{Data Collecting Method}

This research uses primary data that are collected using the enclosed questionnaire about family environment, self-concept, entrepreneurship motivation and interest in entrepreneurship. Self concept were adapted from (Kumari and Chamundeswari, 2013), entrepreneurship motivation were adapted form (Baum, 2007), 2014), risk taking propensity were adapted from Bezzina (2010) and entreprenurial intention were adapted from Khuong, Huu An (2016). All measures collected based on a five point Likert scale in which 1 represents "strongly disagree" and 5 is "strongly agree".

\section{Population and Sample}

2010-2014 forces that are still active in the lecturing process is the selected population. 2010-2014 forces were the selected population because this forces had followed the entrepreneurship courses. In this research the sample was taken using purposive sampling technique. The sample size of this research was determined using the slovin's formula. Total population 8.432 students and the sample 382 students.

\section{Analysis Method}

The analytical method used in this research is multiple linier regression. According to the number of variables in this research, the regression equation used is :

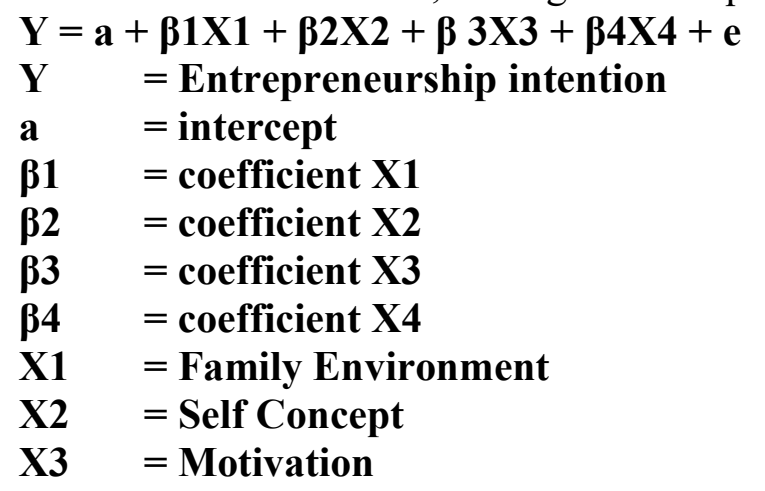




\section{X4 = Risk Taking Propensity}

\section{RESULT AND DISCUSSION}

\section{RESULT}

To understand the characteristics of the variables in terms of minimum value, maximum, average, and standard deviation, the below is the presented descriptive statistical data.

Table 2. Descriptive Statistic

\begin{tabular}{|l|l|l|l|l|}
\hline \multicolumn{1}{|c|}{ Variable } & Minimum & Maximum & Mean & $\begin{array}{c}\text { Std. } \\
\text { Deviation }\end{array}$ \\
\hline Family Environment & $\mathbf{3 8}$ & $\mathbf{5 5}$ & $\mathbf{4 7 . 5 9}$ & $\mathbf{3 . 1 5}$ \\
Self Concept & $\mathbf{2 8}$ & $\mathbf{5 5}$ & $\mathbf{4 0 . 0 8}$ & $\mathbf{5 . 4 9}$ \\
Motivation & $\mathbf{2 6}$ & $\mathbf{6 5}$ & $\mathbf{4 6 . 9 5}$ & $\mathbf{7 . 5 5}$ \\
Risk Taking Propensity & $\mathbf{8}$ & $\mathbf{2 0}$ & 16.84 & $\mathbf{2 . 1 0}$ \\
Entrepreneurship Intention & $\mathbf{2 1}$ & $\mathbf{4 0}$ & $\mathbf{3 3 . 9 5}$ & $\mathbf{2 . 6 9}$ \\
\hline
\end{tabular}

Based on Table 2, the average Family Environment (X1) is 47.59 with the lowest value 38 and the highest was 55. The Standard deviation of the Family Environment is 3.15, lower than the mean value, thus it can be said that the deviations of data that occurs is relatively small.

The average Self Concept (X2) is 40.08 with the lowest value 28 and the highest was 55. The Standard deviation of the Self Concept is 5,49, lower than the mean value, thus it can be said that the deviations of data that occurs is relatively small.

The average Motivation (X3) is 46.95 with the lowest value 26 and the highest was 65 . The Standard deviation of the Motivation is 7,55 , lower than the mean value, thus it can be said that the deviations of data that occurs is relatively small.

The average Risk Taking Propensity (X4) is 16.84 with the lowest value 8 and the highest was 20 . The Standard deviation of the Risk Taking Propensity is 2,10 , lower than the mean value, thus it can be said that the deviations of data that occurs is relatively small.

The average Entrepreneurship Intention (Y) is 33.95 with the lowest value 21 and the highest was 40. The Standard deviation of the Entrepreneurship Intention is 2,69, lower than the mean value, thus it can be said that the deviations of data that occurs is relatively small.

\section{MULTIPLE REGRESSION ANALYSIS}

In this study, the multiple linear regression model is developed to determine the effect of family environment, self-concept, entrepreneurship motivation, risk taking propensity on entrepreneurial intention.

The multiple regression result is shown in Table 3.

Table 3. Multiple Regression Analysis

\begin{tabular}{|l|l|l|l|l|}
\hline No. & Variable & Coefficient & T & Sig. \\
\hline 1. & Cosntrant & 10,564 & & \\
\hline 2. & Family Environment & 0,174 & $4,672^{*}$ & 0,000 \\
\hline 3. & Self Concept & 0,104 & $5,377^{*}$ & 0,000 \\
\hline
\end{tabular}




\begin{tabular}{|l|l|l|l|l|}
\hline 4. & Motivation & 0,153 & $9,992 *$ & 0,000 \\
\hline 5. & Risk taking propensity & 0,224 & $4,368 *$ & 0,000 \\
\hline
\end{tabular}

Notes: *Significant at 5 percent level.

Source: Own development

Multiple regression equation as follows:

$Y=10,564+0,174\left(X_{1}\right)+1,104\left(X_{2}\right)+0,153\left(X_{3}\right)+0,224\left(X_{4}\right)+e$

From Table 3 it can be seen that the influence of each independent variable to the dependent variable is as follows: The regression analysis of the family environment, self concept, motivation and risk taking propensity are signifikan in level of 0,000 , indicate that family environment self concept, motivation and risk taking propensity have siginificant and positive effect to the entrepreneurship intention.

\section{DISCUSSION}

\section{a. Influence of Family Environment $\left(X_{1}\right)$ on the Interests in Entrepreneurship}

The result proves that family environment has significant and positive effect to the entrepreneurship intention. Family environment is the first and foremost media that influence behavior in a child's development. It is called the main environment, because most of their lives are in family, so that the most widely accepted of education are from the family.

Family environment is the environment that covers all interactions and conditions in relation to the implementation of learning efforts and influence on the interests and behavior of children. Therefore, family environment also affects the children's interest in entrepreneurship with the encouragement from the family. Interaction within the family environment such as learning to work together and help each other both in the family and social environment.

Based on the discussion above, family environment can be said as student first social group, the first to provide the planting of values and attitudes for their development. Related with the interest in doing entrepreneurship, family environment with every conditions within it including how parents educate, relationship between family members, house situation, parents understanding, and cultural background will guide and encourage students in doing entrepreneurship.

The results of this study is consistent with the results of the research conducted by (Lindquist et al., 2015, Fatoki, 2014), which states that the parent's support such as support for entrepreneurship activities can affect student interest in doing entrepreneurship. This study also inline with (Ozaralli and Rivenburgh, 2016; Liñán et al. 2005; Mueller 2006) that conclude parental role modeling to be a significant familial factor on entrepreneurial intention.

\section{b. Effect of self-concept $\left(\mathrm{X}_{2}\right)$ on the Interest in Entrepreneurship}

The result proves that self concept has significant and positive effect to the entrepreneurship intention. A person who has interest in entrepreneurship needs to understand his self-concept because self-concept covers the perceptual component which is about appearance, conceptual component of the ability and inability and lastly, the attitude component such as self-esteem, pride and shame.

If a person manages to identify his personality and self-competence well then it will be valuable for his entrepreneurship life. Because for entrepreneurs, self-knowledge is important to recognize the environment and see business opportunities. 
Therefore, in order to encourage a person's interest in entrepreneurship, in this case student, positive self-concept is required as one of the factors that may affect. This is because with a positive self-concept, they will be able to recognize themselves well in terms of attitude, ability, disability, feelings, and emotions so that they have a strong belief that they can see the opportunities around to get the chance that is beneficial.

The results of this study is consistent with the result of the research conducted by Simanjutank et al., (2016), Utsch and Rauch (2000), Mueller and Thomas (2001), Nga and Shanmuganathan (2010), that self-concept is positively affect interest in entrepreneurship, in entrepreneurship selfconcept is useful to recognize environment, see opportunities and use the resources to take advantage of these opportunities and self-confidence.

\section{c. Effect of Motivation ( $\left.\mathrm{X}_{3}\right)$ on the Interest in Entrepreneurship}

The result proves that motivation has significant and positive effect to the entrepreneurship intention. Motivation is important because it is the encouragement to work hard to get many things such as the desire to be a successful entrepreneur, so it can raise the spirit in giving a positive response to the opportunities in obtaining profit for themselves to be independent. Such advantage can be obtained by always trying to create a more efficient way of working to create creative and innovative products.

The results of this research is consistent with the results of research that is conducted by Baum (2007), that motivation has positive effect on interest in entrepreneurship, high motivation in entrepreneurship will support the success of the business. Because higher motivation will make a person be able to overcome any difficulties and he also be able to create the solution.

\section{d. Effect of risk taking propensity $\left(\mathrm{X}_{4}\right)$ on the Interest in Entrepreneurship}

The result proves that risk taking propensity has significant and positive effect to the entrepreneurship intention.From the results of questionnaire research of risk taking propensity $\left(\mathrm{X}_{4}\right)$, it can be seen that students have interest in entrepreneurship in taking risks because high risks will grant high rewards, but the risk is already taken with a strategy to minimize its risk.

The results of this research is consistent with the results of the research conducted by Bezzina (2010) that risk taking propensity $\left(\mathrm{X}_{4}\right)$ has significant and positive effect on the interest in entrepreneurship, an entrepreneur will take the risk after analyzing the situation carefully and have developed a strategy to minimize the impact of the risks.

\section{CONCLUSION AND SUGGESTION}

Family environment, self concept, motivation and risk taking propensity have significant and positive effect on university students on interest in entrepreneurship. Family environment has high effect to encourage university student on the interest in doing entrepreneurship. Self-concept makes a person recognizing the environment easier and quickly and view business opportunities better. Motivation is booster for individual to work hard in order to raise a passion to become entrepreneurs. Risk can be a strategic contributing factor that capable of analyzing the progress of an entrepreneur. Another factor to increase entrepreneurial intention is education (Souitaris et al., 2007, Nakayama, 2016). Next research can consider entrepreneurship education to test the effect on increase entrepreneurial intention 


\section{LITERATURE}

Aldrich, Howard E, Jennifer E. Cliff. (2003). The pervasive effects of family on entrepreneurship: toward a family embeddedness perspective. Journal of Business Venturing, 18: 573-596

Baum. (2007). The Psychology of Entrepreneurship. London : Routledge.

Bezzina, F. (2010). Characteristic of the Maltese Entrepreneur. International journal of Arts and Science. Vol. 3 (7), 292-312

Belás J., Ključnikov, A. (2016). The Most Important Attributes of Entrepreneurs Case Study of the Environtment of Czech SMES. International Journal of Entrepreneurial Knowledge. Volume 4. Issue 1. 104-111

Belas, J., Bilan, Y., Ključnikov, A. Vincurova, Z. Machacek, J. (2015). Actual Problems of Business Risk in SME Segment, Case Study from Slovakia. International Journal of Entrepreneurial Knowledge. Volume 3, Issue 1, 46-56.

Fatoki, O.(2014). Parental and gender effects on the entrepreneurial intention of university students in South Africa. Mediterranean Journal of Social Sciences, 5(7): 157-162.

Gecas, Viktor. 1982. The Self Concept. Annual Review of Sociology, Vol. 8 (1982), pp. 1-33

Gürol, Y., \& Atsan, N. (2006). Entrepreneurial characteristics amongst university students: Some insights for entrepreneurship education and training in Turkey. Education + Training, 48(1), 25-38.

Hmieleski, K. M., \& Corbett, A. C. (2006). Proclivity for improvisation as a predictor of entrepreneurial intentions. Journal of Small Business Management, 44, 45-63.

Kumari, Archana, A. Chamundeswari. (2013). Self-Concept and Academic Achievement of Students at the Higher Secondary Level. Journal of Sociological Research. Vol. 4, No.2, 105113

Khuong, Mai Ngoc, Nguyen Huu An. (2016). The Factors Affecting Entrepreneurial Intention of the Students of Vietnam National University-A Mediation Analysis of Perception toward Entrepreneurship. Journal of Economics, Business and Management, Vol. 4, No. 2.

Liles, P. R. (1974). New business ventures and the entrepreneur. Homewood, IL: Irwin

Liñán, F., Rodriguez-Cohard, J. C., \& Rueda-Cantuche, J. M. (2005). Factors affecting entrepreneurial intention levels. Amsterdam: Paper presented at the 45th Congress of the European Regional Science Association.

Lindquist, M., Sol, J., and Van Praag, C.M. (2015). Why do entrepreneurial parents have entrepreneurial children?. Journal of Labor Economics, 33(2), 269-296

Mueller, S. L., \& Thomas A. S. (2001). Culture and entrepreneurial potential: A nine country study of locus of control and innovativeness. Journal of Business Venturing, 16(1): 51-75.

Mueller, P. (2006). Entrepreneurship in the region: breeding ground for nascent entrepreneurs? Small Business Economics, 27(1), 41-58. 
Nakayama, Takeshi. (2016). Entrepreneurial Intention in Japan: An Empirical Study on Japanese University Students. International Journal of Business and General Management. Vol. 5, Issue 3, Apr - May 2016; 81-96.

Nga, J.K.H., \& Shamuganathan, G. (2010). The influence of personality traits and demographic factors on social entrepreneurship start up intentions. Journal of Business Ethics, 95(2): 259282.

Ozaralli, Nurdan \& Nancy K. Rivenburgh. (2016). Entrepreneurial intention: antecedents to entrepreneurial behavior in the U.S.A. and Turkey. Journal of Global Entrepreneurship Research 6:3: 1-32.

Shapero, A. \& Sokol, L. (1982). The social dimensions of entrepreneurship. In C. Kent, D. Sexton, \& K. Vesper (Eds.),The encyclopedia of entrepreneurship (pp. 72-90). Englewood Cliffs: Prentice-Hall.

Simanjuntak, Megawati, Irma Awwaliyah, Hayati, Rico J. Artanto. (2016). The Entrepreneurial Potential among Undergraduate Students. Jurnal Bisnis \& Manajemen. Vol. XVII, No. 2, 7584

Tyszka, Tadeusz, JerzyCie'slik b, ArturDomuratc, AnnaMackoa. (2011). Motivation, self-efficacy, and risk attitudes among entrepreneurs during transition to a market economy. The Journal of Socio-Economics. SOCECO-1046. PP 1-8

Utsch, A., \& Rauch, A. (2000). Innovativeness and initiative as mediators between achievement orientation and venture performance. European journal of work and organizational psychology, 9(1), 45-62.

Souitaris, Vangelis, Stefania Zerbinati, Andreas Al-Laham. (2007). Do entrepreneurship programmes raise entrepreneurial intention of science and engineering students? The effect of learning, inspiration and resources. Journal of Business Venturing. 22. 566-591 